\title{
Biotin Labeling of Red Cells in the Measurement of Red Cell Volume in Preterm Infants
}

\author{
I. R. B. HUDSON, I. A. J. CAVILl, A. COOKE, B. M. HOLlAND, T. G. HOY, D. TREVETT, \\ T. L. TURNER, AND C. A. J. WARDROP \\ Queen Mother's Hospital [I.R.B.H., A.C., B.M.H., T.L.T.], Glasgow and Department of Haematology [I.A.J.C., \\ T.G.H., D.T., C.A.J.W.J, University of Wales College of Medicine, Cardiff, United Kingdom
}

\begin{abstract}
Determination of circulating red cell volume (RCV) in anemic preterm infants is, in theory, a better indicator of transfusion needs than $\mathrm{Hb}$ concentration. Our study reports the results of RCV measurement using biotin labeling of red cells on $\mathbf{4 0}$ occasions in preterm infants of 25-34 wk gestation. In 20 infants, who had estimations made within $24 \mathrm{~h}$ of birth, the RCV varied between 17.7 and $66 \mathrm{~mL} / \mathrm{kg}$. Twenty measurements were made at a later age at the time of a blood transfusion. RCV values were between 13.1 and $41.5 \mathrm{~mL} / \mathrm{kg}$ before transfusion. In 13 infants, RCV was determined simultaneously using two methods, biotin and dilution of autologous $\mathrm{HbF}$ with donor $\mathrm{HbA}$ at transfusion. There was no significant difference between the results of RCV estimations using these two methods. Our study demonstrates that biotin labeling is an effective method for determining $\mathrm{RCV}$ in preterm infants. (Pediatr Res 28: 199-202, 1990)
\end{abstract}

\section{Abbreviations}

Hct, hematocrit

$\mathrm{RCV}$, red cell volume

The RCV represents the total volume of red cells in the circulation. It has been suggested that the RCV is a better guide to red cell transfusion requirements than $\mathrm{Hb}$ concentration (13 ), which has been shown to be a poor predictor of benefit from blood transfusion (4-6). After acute blood loss and in anemia of prematurity, the $\mathrm{Hb}$ concentration is poorly correlated with $\mathrm{RCV}$; some infants have a very low RCV, yet maintain an adequate $\mathrm{Hb}$ concentration $(1,2,7)$. RCV may also be a more rational physiologic indicator than $\mathrm{Hb}$ concentration of the oxygen carrying capacity of the blood in the whole circulation (3). Low RCV at birth is associated with birth asphyxia $(8,9)$, increasing severity of hyaline membrane disease $(9,10)$, and increased mortality $(8,10)$. RCV estimation has become a vital investigation in adults with polycythemias, some anemias, and the assessment of erythropoiesis (11).

Previously described methods for determining RCV include both techniques using the dilution principle after labeling of red cells with a tracer and indirect methods, which give a calculated $\mathrm{RCV}$ derived from plasma volume and Hct. Radioisotopes as tracers (11) are no longer acceptable in infants. Labeled albumin leaks in an unpredictable manner from the circulation in sick patients (12) and equilibrates with extravascular tissues (13). Therefore, determinations made with labeled albumin tend var-

Received June 19, 1989; accepted April 27, 1990

Correspondence: Dr. B. M. Holland, Queen Mother's Hospital, Yorkhill, Glasgow, G3 8SJ, UK.

Supported by a grant from Scottish Hospitals Endowment Research Trust (I.H.). iably to overestimate plasma volume. Accurate calculation of $\mathrm{RCV}$ from plasma volume requires not only accurate plasma volume estimation but also a knowledge of the total body Hct. Although correction factors allow for the difference between venous and total body $\operatorname{Hct}(14,15,16)$, they are of quite unknown reliability in sick infants.

$\mathrm{RCV}$ can be estimated using dilution of autologous $\mathrm{HbF}$ at the time of a blood transfusion $(2,17)$. This is reliable provided that $\mathrm{HbF}$ estimation is accurate (e.g. alkali denaturation technique) (2) and at least $20 \%$ of the $\mathrm{Hb}$ in the circulation before transfusion is fetal. This technique cannot be used without a donor blood transfusion.

A new method has recently been described for determination of RCV in adults. Biotin is used to label autologous red cells, and their dilution is quantitated in a fluorescence-activated cell sorter using the fluorescein-streptavidin reaction (17). Biotin is not toxic in infants, even in pharmacologic doses (18).

We report here results of a study using biotin labeling of red cells for determination of RCV in preterm infants both within $24 \mathrm{~h}$ of birth and later at the time of transfusion.

\section{MATERIALS AND METHODS}

Infants. RCV determinations were made within $24 \mathrm{~h}$ of birth in 20 preterm infants, 13 male and seven female. Gestational ages at birth were 25-34 wk, birth wt 620-2400 g. Four of the infants were small for gestational age.

$\mathrm{RCV}$ estimations were made in relation to 20 transfusions at a mean age of $25 \mathrm{~d}$ (range 2-40 d) and mean wt of $1.5 \mathrm{~kg}$ (range $0.68-2.9 \mathrm{~kg}$ ). Twelve infants were either being ventilated or receiving supplementary oxygen; the remaining eight were nursed in air at the time of transfusion.

The indications for red cell transfusions were as follows: 1) Infants receiving assisted ventilation or those requiring a fraction of inspired oxygen of greater than 0.4: red cell transfusions were given if more than $9 \mathrm{~mL} / \mathrm{kg}$ of blood had been sampled since birth or the previous transfusion, or if the Hct was less than 0.42 ( $\mathrm{Hb}$ less than $14 \mathrm{~g} / \mathrm{dL}$ ). 2) Infants requiring increased ambient oxygen but a fraction of inspired oxygen less than 0.4 within the first 2 wk of birth: transfusions were given if the Hct was less than $0.36(\mathrm{Hb}$ less than $12 \mathrm{~g} / \mathrm{dL}$ ) or if more than $9 \mathrm{~mL} / \mathrm{kg}$ of blood had been sampled since birth or previous transfusion. 3) Older infants, who were thought to be symptomatic, were given a transfusion if the Hct was less than 0.30 (Hb less than $10 \mathrm{~g} /$ $\mathrm{dL}$ ), or if greater than $9 \mathrm{~mL} / \mathrm{kg}$ of blood had been sampled since the previous transfusion. Asymptomatic infants received blood transfusion if the Hct was less than 0.27 (Hb less than $9 \mathrm{~g} / \mathrm{dL}$ ).

To validate the biotin technique in infants, RCV was determined simultaneously using both the present method and dilution of autologous $\mathrm{HbF}$ with donor $\mathrm{HbA}(2)$ in 13 infants receiving red cell transfusion.

In 18 infants studied just before transfusion, the posttransfusion RCV was calculated from the sum of the measured pretrans- 
fusion value and the volume of transfused red cells. In two cases studied just after transfusion, the pretransfusion RCV value was calculated by subtraction of the volume of red cells transfused.

$\mathrm{Hb}$ concentrations were measured on arterial or venous blood samples with each determination of RCV. The amount of placento-fetal transfusion at birth varied because the timing of cord clamping was uncontrolled.

Ethical approval for this study was obtained from the Hospital Ethics Committee and informed parental consent was obtained before each measurement of RCV.

Determination of $R C V$. Biotin labeling of autologous red cells was used for determination of RCV by a dilution technique. The method was modified from that of Cavill et al. (17). Heparinized blood $(0.5 \mathrm{~mL})$ from the infant was placed in a sterile container, $5 \mathrm{~mL}$ of normal saline added, and the sample centrifuged at 1100 $\mathrm{rpm}$ for $5 \mathrm{~min}$. The red cells were then removed and resuspended in $2 \mathrm{~mL}$ of normal saline. Some of the resuspended sample $(0.3$ $\mathrm{mL}$ ) was kept for a cell count and to form the negative control. The remainder of the sample was incubated for $15 \mathrm{~min}$ at room temperature, with constant agitation for the first $5 \mathrm{~min}$, with $0.35 \mathrm{pg}$ biotin per cell (long chain, water soluble biotin, NHSLC-Biotin Sulfosuccinimidyl 6-(biotinamide) Hexanoate, Pierce Chemical Company, Rockford, IL). The biotin had been reconstituted by dissolving in sterile normal saline and filtering through a $0.2 \mu \mathrm{m}$ filter. After incubation, the cells were washed twice and resuspended to $1.3 \mathrm{~mL}$. Some of this suspension $(0.3 \mathrm{~mL})$ was kept for a cell count and to form the positive control. The remainder was reinjected into the infant.

At 10 and $30 \mathrm{~min}$ after reinjection, $0.3 \mathrm{~mL}$ blood was taken from the infant. A cell count was performed on part of each sample. Ten million cells of duplicates of the negative control, positive control, and 10- and 30-min samples were then resuspended in $1 \mathrm{~mL}$ cold PBS. Ten $\mu \mathrm{L}$ of fluorescein-streptavidin (Amersham International plc. Amersham, Buckinghamshire, UK) were added to each of the eight tubes; incubation was over $30 \mathrm{~min}$ at $2-4^{\circ} \mathrm{C}$, with agitation every $10 \mathrm{~min}$. After incubation, the cells were washed twice and resuspended in $1 \mathrm{~mL}$ particlefree saline for counting. One million cells from each of the eight tubes were counted on a fluorescence-activated cell sorter (Becton-Dickinson "FACS 440"). The cells were excited at a wavelength of $488 \mathrm{~nm}$ with an argon laser and analyzed at $535 \mathrm{~nm}$. The labeled cells were readily distinguishable from the unlabeled cells and, therefore, the proportion of cells fluorescing could be determined. The negative control was used to give the background fluorescence (normally $<0.03 \%$ ), which was subtracted from the 10- and 30-min samples. The positive control confirmed effective binding (normally $\sim 99 \%$ ). The RCV can be calculated from the equation:

\section{$\mathrm{RCV}(\mathrm{mL} / \mathrm{kg})$}

$$
=\frac{\text { vol inject } \times \mathrm{RCC} \times \% \text { positive control } \times \mathrm{MCV}}{\% \text { positive samples } \times 1000 \times \text { wt }(\mathrm{kg})}
$$

where vol inject is the volume of blood reinjected into the infant, $\mathrm{RCC}$ is the red cell count of the reinjected sample, \% positive control is the \% positively labeled cells in the positive control, $\mathrm{MCV}$ is the mean cell volume (fL) (determined on an unlabeled sample) needed to convert a cell count into a volume, and \% positive samples is the mean of the proportion of positive cells in the 10- and 30-min samples minus negative control.

\section{RESULTS}

$\mathrm{RCV}$ values within $24 \mathrm{~h}$ of birth (including allowance for sampling blood losses), as shown in Figures 1 and 2, ranged from 17.7-66.5 mL/kg, mean $34.2 \mathrm{~mL} / \mathrm{kg}$. In one growth-retarded infant of $33 \mathrm{wk}$ gestation, the RCV was $66.5 \mathrm{~mL}$ and the venous Het was 0.63 . The small-for-gestational-age infants as a group had a mean $\mathrm{RCV}$ of $44.2 \mathrm{~mL} / \mathrm{kg}$. RCV values calculated from the samples obtained $10 \mathrm{~min}$ after reinjection showed no signif-

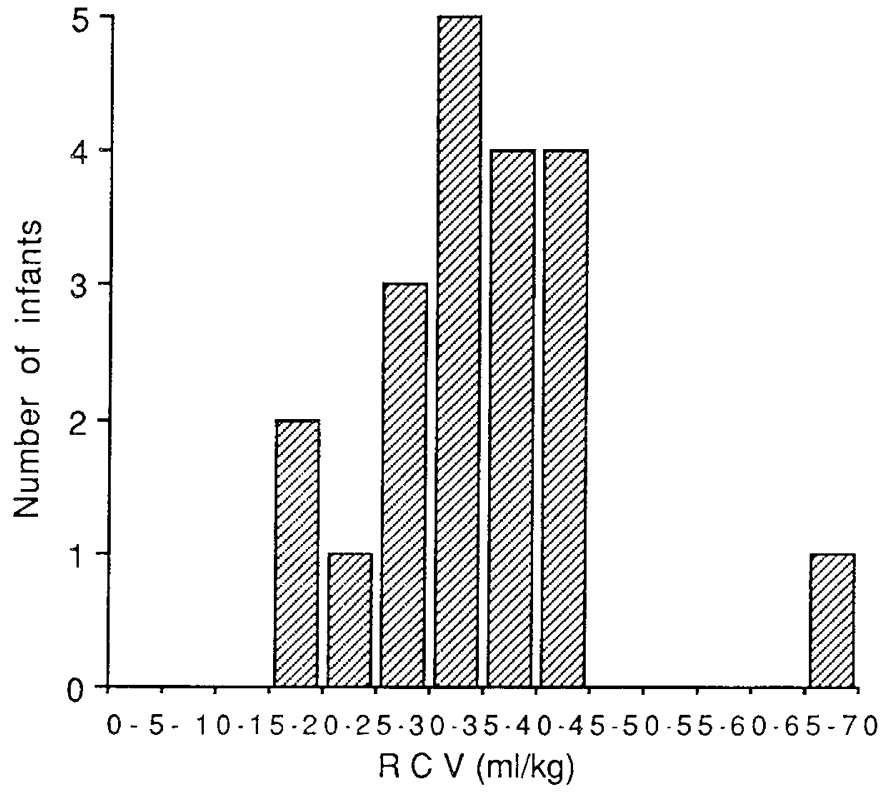

Fig. 1. Results of RCV determination within $24 \mathrm{~h}$ of birth in 20 preterm infants.

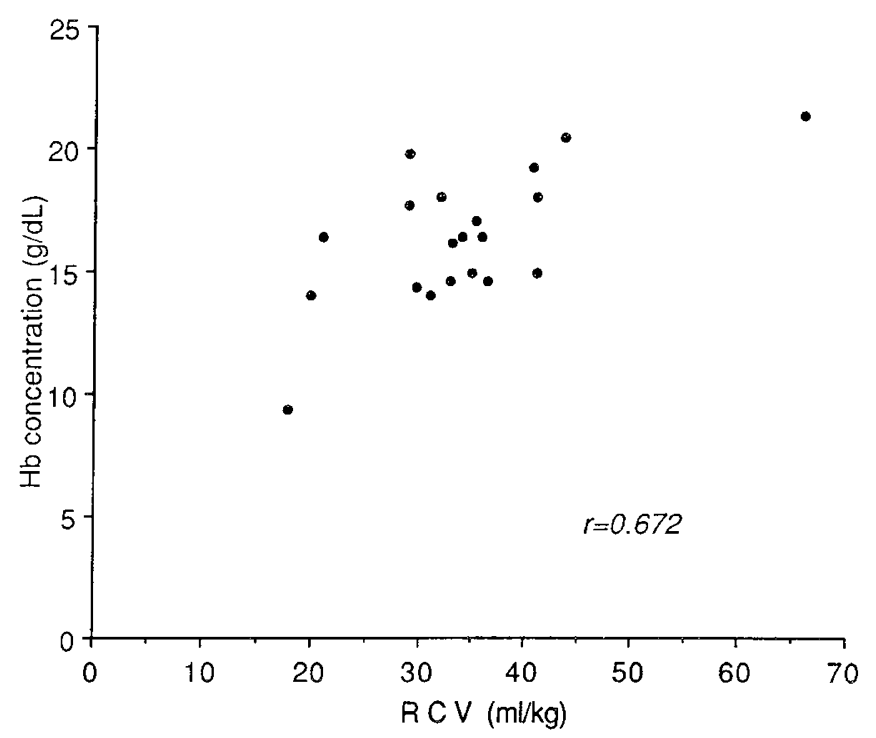

Fig. 2. Relationship between $\mathrm{Hb}$ concentration and $\mathrm{RCV}$ within 24 $h$ of birth in 20 preterm infants.

Table 1. $R C V$ determination within $24 h$ of birth in relation to gestational age

\begin{tabular}{cccr}
\hline \multirow{2}{*}{$\begin{array}{c}\text { Gestational age } \\
\text { (wk) }\end{array}$} & $n$ & Mean & SD \\
\cline { 3 - 4 } $25-27$ & 3 & 22.2 & 6.1 \\
$28-30$ & 6 & 35.3 & 3.9 \\
$31-32$ & 4 & 41.9 & 17.3 \\
$33-34$ & 7 & 34.1 & 7.2 \\
\hline
\end{tabular}

icant difference from those determined from the samples taken at $30 \mathrm{~min}$, implying adequate mixing at the earlier time. Mean Apgar scores at $5 \mathrm{~min}$ in infants with $\mathrm{RCV}<30 \mathrm{~mL} / \mathrm{kg}$ were 7.3 , with RCV $30-40 \mathrm{~mL} / \mathrm{kg}, 7.7$, and with $\mathrm{RCV}>40 \mathrm{~mL} / \mathrm{kg}$, 8.8; the differences were not statistically significant. There was no significant correlation with gestational age although the two infants of shortest gestation had the lowest RCV values. Table 1 shows RCV values in relation to gestational age at birth.

Three of the infants subsequently died, two from complica- 

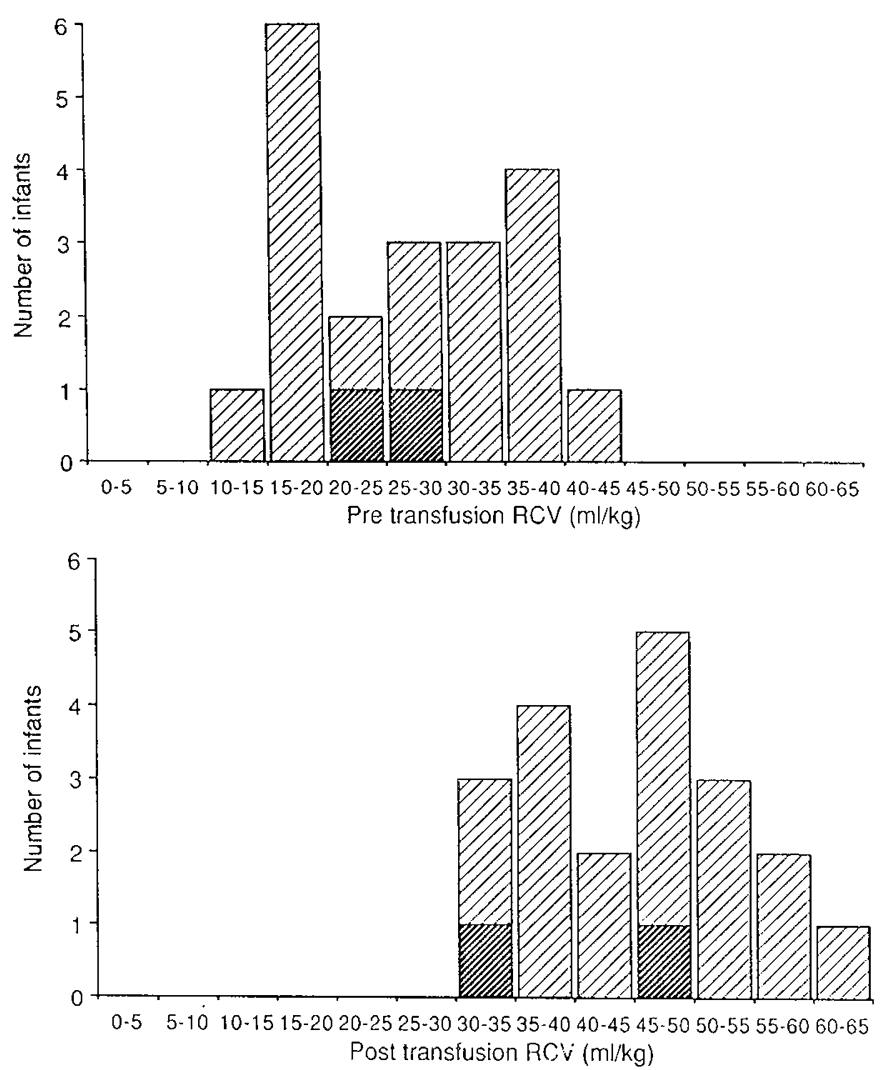

Fig. 3. Results of RCV determination at the time of red cell transfusion in 20 preterm infants. RCV was measured in 18 cases before and in two cases after transfusion, the corresponding post- or pretransfusion volumes were calculated by adding or subtracting, respectively, the volume of the transfused cells. These cases are indicated by dark hatches.

Table 2. $R C V$ determinations in relation to blood transfusion at mean age of $25 \mathrm{~d}$ (range $1-90 \mathrm{~d}$ )

\begin{tabular}{|c|c|c|c|}
\hline & \multirow[b]{2}{*}{$n$} & \multicolumn{2}{|c|}{$\begin{array}{c}\text { Pretransfusion RCV } \\
(\mathrm{mL} / \mathrm{kg})\end{array}$} \\
\hline & & Mean & $\mathrm{SD}$ \\
\hline \multicolumn{4}{|c|}{ Gestational age at birth (wk) } \\
\hline $26-27$ & 8 & 32.4 & 6.9 \\
\hline $28-29$ & 7 & 23.7 & 7.4 \\
\hline $30-31$ & 3 & 27.8 & 11.4 \\
\hline $32-33$ & 2 & 16.7 & 0.1 \\
\hline \multicolumn{4}{|c|}{ Postconceptual age at transfusion (wk) } \\
\hline $26-27$ & 5 & 28.4 & 8 \\
\hline $28-29$ & 4 & 30.6 & 9.1 \\
\hline $30-31$ & 4 & 32.3 & 9.1 \\
\hline $32-33$ & 2 & 18 & 2.3 \\
\hline $34-35$ & 1 & 18 & \\
\hline $36-37$ & 2 & 25.3 & 12.8 \\
\hline $38-39$ & 2 & 14.9 & 2.6 \\
\hline
\end{tabular}

tions of prematurity (intraventricular hemorrhage and severe idiopathic respiratory distress syndrome) and one from severe cyanotic heart disease. The two infants who died from complications of prematurity had the lowest RCV values, 17.7 and 19.8 $\mathrm{mL} / \mathrm{kg}$.

$\mathrm{Hb}$ concentration and $\mathrm{RCV}$ within $24 \mathrm{~h}$ of birth were correlated, but not very closely $(r=0.678)$. The correlation between Hct and RCV in older infants being transfused $(r=0.698)$ was similar to that at birth. Because of insufficient data in severe anemia, its effect on the Hct-RCV relationship could not be examined.

RCV values determined before transfusions are shown in

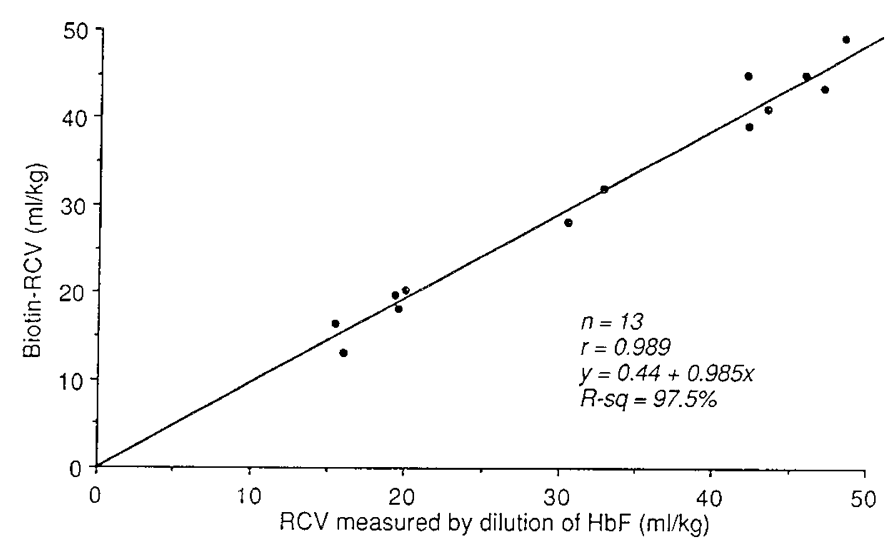

Fig. 4. Relationship between RCV determined by two independent methods: dilution of $\mathrm{HbF}$ and biotin labeling.

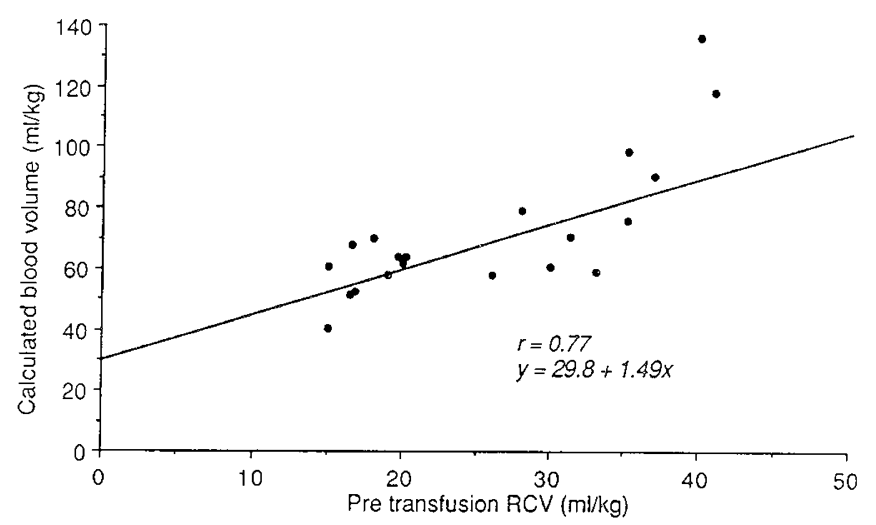

Fig. 5. Relationship between RCV and calculated blood volume before red cell transfusion in 20 preterm infants. No correction factors for total body hematocrit:venous hematocrit have been applied.

Figure 3 and ranged from $13-41 \mathrm{~mL} / \mathrm{kg}$, median $26.3 \mathrm{~mL} / \mathrm{kg}$; the corresponding $\mathrm{Hb}$ concentrations were $7.9-17.7 \mathrm{~g} / \mathrm{dL}$, median $12.0 \mathrm{~g} / \mathrm{dL}$. Posttransfusion RCV ranged from $32-60 \mathrm{~mL} /$ $\mathrm{kg}$, median $44.4 \mathrm{~mL} / \mathrm{kg}$; corresponding $\mathrm{Hb}$ concentrations were $15.2-20.7 \mathrm{~g} / \mathrm{dL}$, median $17.8 \mathrm{~g} / \mathrm{dL}$. Table 2 shows infants' RCV values at the time of transfusion in relation to the infants' gestational age at birth and their postconceptual age (i.e. gestational age at birth plus postnatal age).

$\mathrm{RCV}$ estimations were repeated in some infants. Total clearing of labeled cells occurred in approximately 3-4 wk. If repeat measurements were made before this time had elapsed, the negative control (background fluorescence) was higher, but RCV estimation was still possible.

As shown in Figure 4, results of RCV estimated simultaneously using biotin and dilution of $\mathrm{HbF}$ by donor $\mathrm{HbA}$ are similar. Neither the ranked pair differences nor the median of the two estimations were significantly different $(p>0.05)$.

In infants needing transfusion, the pretransfusion blood volume was estimated using the RCV and Hct. Correction factors for venous to total body Hct have not been applied. The results are shown on Figure 5. There appears to be an association between a low RCV and a low circulating blood volume thus calculated, providing the ratio of total body Hct to venous Hct remains constant and is unity.

\section{DISCUSSION}

This study was designed to develop and evaluate biotin tracer labeling of red cells for measuring $\mathrm{RCV}$ in newborn infants. Biotin as a tracer has been validated in adults by ${ }^{51} \mathrm{Cr}$ determination of RCV made simultaneously with biotin estimations (17). Our study validates the measurement in infants by comparing RCV determination made simultaneously by both biotin 
labeling and dilution of fetal $\mathrm{Hb}$ by donor adult $\mathrm{Hb}$ at transfusion. Total clearing of labeled cells appeared to take 3-4 wk, which is several times longer than in adults. It is not clear why there should be a difference between infants and adults. Both the site of binding of biotin to the surface of the red cell and the mechanism of clearance of labeled red cells are unknown. This delay in clearing labeled red cells does not preclude repeated measurements; several infants have had serial estimations of $\mathrm{RCV}$ made at intervals of $4-7 \mathrm{~d}$ or more without difficulty. The background fluorescence in the negative controls in these infants is higher, but allowance can be made for this by subtracting the background fluorescence from the samples taken at 10 and 30 min.

Estimations of RCV were made in infants receiving parenteral nutrition or enteral breast or formula milk. The technical problems encountered in adults who had consumed avidin-containing foods such as eggs (17) did not arise in this study.

The values for RCV in 20 preterm infants accorded with those of others $(2,6,7,9,16,19,20)$. Our relatively small numbers and bias toward extreme prematurity in the infants with the lowest RCV limited the opportunity of analysis of the outcome in relation to $\mathrm{RCV}$. It is, however, of interest to note that the two infants with the lowest $\mathrm{RCV}$ were those who died from complications of prematurity. Our study supports the association between low RCV and birth asphyxia $(8,19)$.

The varied relationship between $\mathrm{RCV}$ and $\mathrm{Hb}$ concentration (or Hct) has been noted before $(1,2,7)$. Our findings emphasize this important point both at birth and pretransfusion. As previously noted, the RCV in anemic infants may be very low, yet the $\mathrm{Hb}$ concentration may be well maintained $(1,2,7,8)$. In our study, seven out of $20 \mathrm{RCV}$ values before transfusion were less than $20 \mathrm{~mL} / \mathrm{kg}$, yet in only one baby was the corresponding $\mathrm{Hb}$ concentration less than $10 \mathrm{~g} / \mathrm{dL}$. Thus, further evidence is provided that the $\mathrm{Hb}$ concentration (or Hct) may mask a serious deficiency of circulating red cells. The overlap of pre- and posttransfusion $\mathrm{RCV}$ values and $\mathrm{Hb}$ concentrations is not surprising given the heterogeneity of clinical problems and decisions on indications for red cell transfusion. This technique may permit rational prescribing of red cells based on RCV to endow the infant with a RCV sufficient to meet anticipated oxygen requirements (3). This cannot be accurately predicted from the Hct (1).

The circulating blood volume was calculated indirectly from the RCV and the central Hct. This may not be accurate. It is important to note that without reliable plasma volume estimation made simultaneously with RCV determination, total blood volume cannot be accurately established. In view of the unreliability of albumin as a circulating plasma label $(12,13)$, the true total body to venous Hct ratio is unknown in sick, preterm infants. Although this ratio has been assumed to be linear throughout the whole RCV range, this might not be valid. It has been suggested that the blood volume to Hct ratio in sick and anemic infants is lower than in healthy infants $(21,22)$. As noted by Mollison (23), in sick patients the volume of distribution of small molecules such as albumin unpredictably exceeds the volume of distribution of the red cells, rendering inaccurate the estimation of circulating plasma volume using labeled albumin. Variably increased capillary permeability is at the root of this problem $(13,23)$. In such patients, accurate means of estimating true circulating plasma volume have eluded investigators.

Knowledge of the whole body Hct is important in accurate assessment of polycythemia, but arterial blood Hct may be more relevant as a representation of oxygen transport capacity in the circulation. The result of this calculation of blood volume implies a reduction in blood volume associated with a deficiency of circulating red cells. This could offer the advantage of maintaining the Hct and therefore systemic oxygen transport at a given cardiac output, but at the expense of poor perfusion of some parts of the circulation such as the splanchnic bed, lung, and skin.
Our study demonstrates that biotin labeling of red cells is a safe and effective technique for determining the RCV in preterm infants. The technique requires a flow cytometer and takes about $4 \mathrm{~h}$ to perform, but is likely to be of special value in selected sick infants in whom appropriate management depends on the quantitation of abnormalities in RCV. In adults, determination of $\mathrm{RCV}$ is essential in the investigation of polycythemia and some anemias and in the assessment of erythropoiesis. Determination of RCV using biotin as a tracer should permit these pathologic states to be investigated in the newborn, leading to improvements in the diagnosis and clarification of their pathology.

Acknowledgments. The authors thank Jean Hyslop of the Medical Illustration Department, Royal Hospital for Sick Children, Glasgow for assistance with the illustrations and Karyn Black for typing the manuscript.

\section{REFERENCES}

1. Holland BM. Jones JG. Wardrop CAJ 1987 Lessons from the anemia of prematurity. Hematol Oncol Clin North Am 1(3):355-366

2. Phillips HM. Holland BM. Abdel-Moiz A, Fayed S, Jones G, Turner T, Wardrop CAJ, Cockburn F 1986 Determination of red cell mass in the assessment and management of anaemia in babies needing blood transfusion. Lancet 1:882-884

3. Jones JG. Holland BM, Kinmond S, Phillips HM, Turner T, Wardrop CAJ 1989 Prediction and attainment of optimal red cell mass in neonates. Pediatr Res 25:374A(abstr)

4. Blank JP, Sheagren TG, Vajaria J, Mangurten HH, Benawra RS, Puppala BL 1984 The role of RBC transfusion in the premature infant. Am J Dis Child 138:831-833

5. Alverson DC. Isken VH, Cohen RS 1988 Effect of booster blood transfusions on oxygen utilisation in infants with bronchopulmonary dysplasia. J Pediatr 113:722-726

6. Keyes WG, Donohue PC. Spivak JL, Jones MD, Oski FA 1989 Assessing the need for transfusion of premature infants and role of hematocrit, clinical signs and erythropoietin level. Pediatrics 84:412-417

7. Blanchette VS, Zipursky A 1984 Assessment of anemia in newborn infants. Clin Perinatol 11(2):489-510

8. Faxelius G. Rayne J, Gutberlet R, Swanstrom S, Tsiantos A, Dolanski E. Dehan M. Dyer N. Lindstrom D, Brill AB, Stahlman M 1977 Red cel volume measurements and acute blood loss in high-risk newborn infants. $J$ Pediatr 90:273-281

9. Linderkamp O, Versmold HT. Fendel H, Reigel KP, Betke K 1978 Association of neonatal respiratory distress with birth asphyxia and deficiency of red cel mass in premature infants. Eur J Pediatr 129:167-173

10. Usher RH, Saigal S, O'Neil A, Surainder Y, Chua L 1975 Estimation of red cell volume in premature infants with and without respiratory distress syndrome. Biol Neonate 26:241-248

11. Lewis SM, Liu Yin JA 1986 Blood volume studies. In: Lewis SM (ed) Methods in Haematology: Radioisotopes in Haematology. Churchill Livingstone. Edinburgh, pp 198-213

12. Linderkamp OL 1982 Placental transfusion: determinants and effects. Clin Perinatol 9(3):559-592

13. Zikria BA. King TC, Stanford J, Freeman HP 1989 A biophysical approach to capillary permeability. Surgery 105:625-631

14. Mollison PL, Veall N, Cutbush M 1950 Red cell and plasma volume in newborn infants. Arch Dis Child 25:242-253

15. Bratteby LE 1967 Studies on erythro-kinetics in infancy. VIII: Mixing, disappearance rate and distribution volume of labelled erythrocytes and plasma proteins in early infancy. Acta Soc Med Ups 72:249

16. Robinson RO, Emerson PM, Howes D, Fujimura M, Howat P, Salisbury DM 1978 Red cell mass and blood volume in low birth weight infants. J Perinat Med 6:213-219

17. Cavill I, Trevett D, Fisher J, Hoy $\Upsilon 1988$ The measurement of total volume of red cells in man: a non-radioactive approach using biotin. $\mathrm{Br} \mathrm{J}$ Haematol 70:491-493

18. Roth KS 1981 Biotin in clinical medicine: a review. J Clin Nutr 34:1967-1974

19. Linderkamp O, Versmold HT, Messow-Zahn K, Muller-Holve W, Reigel KP. Betke K 1978 The effect of intra-partum and intra-uterine asphyxia on placental transfusion in premature and full term infants. Eur $\mathrm{J}$ Pediatr 127:91-99

20. Bratteby LE 1968 Studies on erythro-kinetics in infancy. XI: The change in circulating red cell volume during the first five months of life. Acta Paediat Scand 57:215-224

21. Linderkamp O, Betke K, Fendel H, Klemm J, Lorenzen K. Riegel KP 1980 Tc-99m-labelled red blood cells for the measurement of red cell mass in newborn infants: concise communication. J Nucl Med 21:637-640

22. Phibbs RM, Johnson P, Tooley WH 1974 Cardio-respiratory status of erythroblastotic newborn infant: blood volume and serum albumin concentrations in red cell in relation to hydrops fetalis. Pediatrics 53:13-23

23. Mollison PL 1983 Blood Transfusion in Clinical Medicine. 7 th ed. Blackwell. Oxford, p 92 